\title{
UTILIZAÇÃO DE ANIMAIS NÃO HUMANOS NA PESQUISA ODONTOLÓGICA
}

Joslei Carlos BOHN, Karine Fátima LYKO, Iran VIEIRA, Ângela FERNANDES, Antonio Adilson Soares de LIMA

Os defensores do bem-estar animal acreditam que cada criatura individual tem um valor intrínseco que deve ser respeitada e protegida. No Brasil, não há registros oficiais do número e grupos taxonômicos dos animais utilizados em pesquisa pela Odontologia. Este trabalho investigou o uso de animais em experimentação nos resumos publicados nos Anais da SBPqO dos três últimos anos segundo a origem geográfica dos trabalhos, os grupos taxonômicos dos animais e o grau de invasividade dos procedimentos. Foram apresentados 7.922 trabalhos e destes 675 envolviam experimentos com animais. Os animais utilizados foram: ratos, coelhos, cães, gambás, porcos, guinea-pigs e macacos. Todos os estudos foram desenvolvidos em Instituições de Ensino Superior (IES) distribuídas em 17 estados brasileiros. A maioria dos trabalhos foi realizada no estado de São Paulo (442), seguido do Paraná (66) e Minas Gerais (55). Quanto ao grau de invasividade: 58\% (397) dos estudos sacrificaram seus animais ao final do experimento. Procedimentos como indução de doença periodontal, inserção de implante e testes de biomateriais também foram realizados. Os resultados demonstraram que as pesquisas brasileiras realizadas com animais, na sua maioria, usam ratos, sacrificam os animais ao final do experimento e são oriundas principalmente de IES localizadas no sudeste do país.

Palavras-chave: Odontologia, Bioética, Animais 